\title{
Äldre kvinnor och män i två dagstidningar: En genuskritisk komparativ studie
}

\section{Gunilla Byrman \& Astrid Skoglund}

I denna artikel fokuserar vi på hur tidningar framställer kvinnor och män över 70 år i sin lokala eller regionala nyhetsrapportering. Ett skäl är att tidigare forskning visar att äldre personer är underrepresenterade i medierna, och medierepresentationen av äldre har traditionellt sett varit stereotyp och nära sammankopplad med teman som beroende, utsatthet och sjukdomar (Nilsson \& Jönsson 2009).

Ett annat skäl att behandla detta ämne är att äldre är en stor och heterogen grupp i samhället nu när den stora gruppen av 40-talister blir äldre. Hälften av alla 40-talister är i pension $\mathrm{nu}$, men det framgår av olika vetenskapliga rapporter att de håller sig à jour med vad som händer, exempelvis är de flitiga internetanvändare. Olle Findahl, professor i media och kommunikationsvetenskap, skriver följande: ’De flesta av de som är äldre än 65 år idag kommer att leva tio eller tjugo år till. De är medborgare precis som alla andra, även om de växt upp, arbetat och levt största delen av sina liv i en annan tid. De har rätt att bli hörda. Det här är ett sätt göra pensionärerna synliga i internets tidevarv" (Findahl 2015:4). Cecilia Gustavsson, journalist på Aftonbladet skriver raljerande följande om 40-talisterna: "De är många, bossiga och uppväxta med guldsked i mun. Men så får också 40-talisterna höra att de är den bortskämda jätteproppen Orvar. Köttberget. I dag sitter 68-vågens rebeller nöjda med bra pension i sina sedan länge avbetalda villor. Passar barnbarnen? Nja. De tar hellre en hälsoresa till Portugal.” Vi kan konstatera att dagens 70-75-åringar är en stor grupp, en grupp som fortfarande är att räkna med och som det har skrivits en hel del medietexter om.

Materialet i denna studie uppvisar enskilda män och kvinnor som tidningarna på ett eller annat sätt betraktat som intresseväckande för läsekretsen. Texterna kan innehålla sociala konstruktioner som läsarna inte märker vid en hastig genomläsning, men som kan bli tydliga vid en närläsning och i ett större material. Detta gäller inte minst genuskonstruktionerna i materialet. I tidningstexter återspeglas samtiden, och därför är den världsbild som tidningarna återger ett bra sätt att se den berättade verkligheten och hur tidningarna vinklar dessa berättelser (Lundström 2004:26-28).

Forskning har tidigare fastslagit att kvinnor inte i lika hög grad som män förekommer i medier (se t.ex. Byrman 2004 och 2015, GMMP 2016, Jarlbro 2006, Ross 2012). Därför vill vi undersöka representationen av personer över 70 år i relation till genus som social kategori, men även de representerade äldres etniska bakgrund och sociala status berörs. Vi belyser även vilket innehåll som dominerar i texter med äldre som huvudpersoner, eftersom valet av innehåll kan antas säga mycket om vilken bild av äldre tidningarna förmedlar till sina läsare.

Nedan presenteras studiens syfte, forskningsfrågor, tidigare forskning, teoriram, metod och material. Därefter redovisas resultaten tillsammans med illustrativa exempel från det studerade materialet. Avslutningsvis summerar och diskuterar vi resultaten mot bakgrund av tidigare forskning om medieinnehåll. 


\section{Syfte och frågor}

Syftet är att undersöka hur kvinnor och män över 70 år språkligt och innehållsligt representeras i artiklar från två sydsvenska dagstidningar - en regional och en lokal. Vi vill besvara följande frågor:

- Hur ser representationen av äldre personer ut kopplat till genus samt etnisk och social bakgrund?

- Vilka teman dominerar i de texter där äldre personer är huvudpersoner, och hur framställs genus i relation till dessa teman?

- Vilka generella skillnader finns det mellan hur kvinnor respektive män framställs i dagstidningarnas lokala rapportering?

Alla artiklarna i materialet är rikt bildsatta. Därför kommenterar vi bildmaterialet, men utan att göra en djupanalys av bildinnehåll.

\section{Tidigare forskning om äldre- och genuskonstruktioner i medier}

Det finns en del tidigare forskning om hur äldre representeras i medier (se t.ex. Bailey 2010, Nilsson 2008 och Fealy m.fl. 2012). Forskningen visar i korthet följande:

- Personer över 65 år är en underrepresenterad grupp i medier.

- Nyhetsdiskurser om äldre fokuserar på motsättningar och problem.

- Personporträtt fokuserar på utveckling, goda vändpunkter, på lärdomar från förr och på tillförsikt inför framtiden.

- Motberättelser om friska och aktiva pensionärer med makt över sina egna liv har börjat bli vanligare sedan 40-talisterna börjat gå i pension; i denna motdiskurs framträder friska pensionärer som fortfarande är yrkesverksamma och engagerade i dagens samhällsliv.

Resultaten ovan bygger främst på samhällsvetaren Magnus Nilssons undersökning av hur äldre framställs i Dagens Nyheter och Aftonbladet (Nilsson 2008). Hans studie med material från år 2002 och 2004 visar att tidningarnas dominerande diskurs om äldre och åldrande konstruerar äldre som offer för sjukdomar, åldersprocessen och bristande vård. Nilssons studie tyder också på att äldre som grupp ofta konstrueras som passiva, medan tidningarnas personporträtt av enskilda äldre oftare uppvisar motberättelser och fokuserar på personer som beskrivs som aktiva pensionärer (Nilsson 2008:99). I en diskursanalytisk studie med material hämtat från irländska tidningar visar Fealy m.fl. (2012:85) att äldre konstrueras som en homogen åldersgrupp som främst utmärks av sitt beroende av samhällets insatser. I den irländska studien var det alltså en tydlig problemdiskurs om äldre som dominerade i mediernas nyhetsrapportering, vilket ligger i linje med huvudresultatet i Nilssons studie från 2008. Det ska dock påpekas att studien av Fealy m.fl. (2012) genomfördes i samband med en kritiserad äldrereform på Irland, vilket troligen har påverkat resultatet och gör att resultatet är svårt att jämföra med svenska förhållanden. 
Vi har inte funnit studier som specifikt fokuserar på hur äldre representeras i relation till genus i lokala eller regionala medier i Sverige. Däremot finns tidigare forskning som visar att kvinnor generellt inte i lika hög grad som män förekommer i medier (se t.ex. Jarlbro 2006 och Edström \& Jacobsson 2015). Vidare har Byrman (2004 och 2015) konstaterat i sin forskning om tidningarnas familjesidor att män ägnas mer textutrymme än kvinnor och att genus, dvs. den sociala konstruktionen av kön fortfarande görs på ett häpnadsväckande traditionellt sätt (jfr även Edström \& Jacobsson 2015).

\section{Material och urval}

Materialet består av 40 bildsatta redaktionella artiklar, varav 20 från Sydsvenska Dagbladet (SDS) och 20 från Smålandsposten (Smp). SDS har en regional läsekrets och vidare spridningsområde än Smp och betecknar sig som "oberoende liberal". Smp har lokal täckning i Växjö med omnejd i södra Småland. Tidningen verkar enligt ledarredaktionen för: "kristna värderingar, konservativ ideologi i förening med liberal idétradition samt för näringsfrihetens och äganderättens bevarande."

Artiklarna excerperades under fyra insamlingsveckor från december 2014 till september 2015. Materialet kan betecknas som ett strategiskt bekvämlighetsurval, eftersom vi valt längre artiklar från tidningar som varit tillgängliga för oss. Gemensamt för artiklarna i materialet är att de har en huvudperson som är 70 år eller äldre, och artiklarna överstiger notisformat, det vill säga 150 ord (Byrman 1998:13). Texter från Familjesidan är bortvalda, eftersom många av texterna där skrivs av anhöriga, och därmed är dessa texter inte att betrakta som redaktionellt material.

\section{Teori och metod}

Vi utgår från kritisk diskursanalys (Fairclough 2010) som kombineras med ett genusperspektiv där vi ser genus som en social konstruktion av kvinnors och mäns könsidentiteter. Nordenstam påpekar att: "Kön/genus betraktas alltså inte längre som en universell kategori utan dekonstrueras. Det finns de som relativiserar manlighet och kvinnlighet till helt flytande kategorier. [...] I forskningstraditioner med mera pragmatisk inriktning betonas den sociala kontextens betydelse" (Nordenstam 2003:43). Vi anlägger också delvis ett intersektionellt perspektiv med fokus på framför allt ålder och genus, men vi försöker även belysa etnicitet och social tillhörighet. Den kritiska diskursanalysens premisser är att sociala identiteter, maktrelationer, kunskaps- och värdesystem skapas, bevaras och synliggörs i den sociala, diskursiva och textuella praktiken (Fairclough 2010). I den intersektionella analysen studeras olika kategorier (se de los Reyes \& Mulinari 2005) och hur kategorierna kan relateras till varandra. Intersektionalitet härstammar från en feministisk kritisk teori och fungerar som ett analytiskt hjälpmedel för att studera hur maktordningar, som diskriminerar i ett samhälle, samverkar (jfr Crenshaw 2008). När begreppet intersektionalitet började användas framhölls det att det var en modell som pekade på normbrytande erfarenheter. Intersektionalitet har sitt ursprung i 1980-talets USA och är en inomfeministisk kritik. Kritiken handlade om att den feministiska rörelsens perspektiv framför allt utgick från vita heterosexuella medelklasskvinnor. Detta osynliggjorde andra kvinnors situationer (Nygren 2012:16-18). 
Diskriminering på basis av kön, ålder, social status och etnicitet samverkar och kan i vissa fall förstärka varandra. Intersektionalitet kan fungera som hjälpmedel, som inte strävar efter att rangordna identitetskonstruktioner utan efter att synliggöra hur olika maktordningar är sammanvävda på politiska och representationella nivåer. Med ett intersektionellt perspektiv ställs frågor om hur makt och ojämlikhet vävs in i uppfattningen om identitetskategorier; antagandet är att olika maktordningar är beroende av varandra, och det är därför meningsfullt att se till hur olika sociala kategorier samverkar (se vidare Crenshaw 2008 och de los Reyes \& Mulinari 2005).

Vår undersökning fokuserar främst på variablerna genus och ålder. De äldres sociala status och etnicitet avgränsas till en kartläggning av explicita, språkliga markörer, som kan antas definiera personens etniska eller sociala bakgrund. Till sådana språkliga markörer hör namn, uppgifter om födelseort samt epitet som på ett eller annat anger om den omtalade personens verksamhetsbeteckning, yrkesbeteckning eller titel och som säger något om en persons sociala position (jfr Bourdieu 1999).

Metoden är närläsning av artiklarna med analys och kvantifiering av de nämnda kategorierna: genus, ålder, etnicitet och social status och ett antal teman som blir synliga i näranalysen. I temana undersöks hur äldre framställs i relation till andra sociala kategoriseringar och vilken eller vilka kategorier som spelar störst roll i de teman som äldre synliggörs i. Således pendlar vi i analysen mellan kvantitativ och kvalitativ metod.

I det följande kommer vi att redovisa analysen och resultaten genom att visa på hur de studerade kategorierna blir synliga och olika frekventa teman i artiklarna.

\section{Analys av genus, ålder, etnicitet och social status}

Nedan kommer vi att redovisa resultaten av analysen; det gäller genus, ålder, etnicitet och social status. I tabell 1 presenteras det studerade materialets sammansättning av manliga och kvinnliga intervjupersoner.

\begin{tabular}{|c|c|c|c|}
\hline 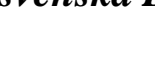 & Smp & SDS & Totalt \\
\hline Kvinnor & 13 & 15 & $\begin{array}{l}55 \% \\
28\end{array}$ \\
\hline Män & 10 & 13 & $\begin{array}{l}45 \% \\
23\end{array}$ \\
\hline Totalt & & & $\begin{array}{l}100 \% \\
51\end{array}$ \\
\hline
\end{tabular}

Kvinnorna är något fler än männen i materialet. Av totalt 51 representerade personer från 70 år och uppåt är 28 kvinnor och 23 män, vilket framgår av tabell 1. Även om vi kan konstatera att kvinnorna är i majoritet, kan vi inte dra några säkra slutsatser eftersom materialet är så litet. Vi kan enbart peka på tendenser, som trots allt säger något om hur det skrivs om kvinnor och män i just dessa dagstidningar. Något som inte framgår av tabellen, men som vi har uppmärksammat i vår närläsning, är att kvinnor också upptar mest textutrymme i materialet sett till omfattningen av citat och referat. Det är även kvinnor som står i förgrunden i majoriteten 
av materialets bilder, inte minst i artiklar som rapporterar om lokala evenemang. En förklaring till detta kan vara att de äldre kvinnorna är mer aktiva i lokala aktiviteter och i det lokala föreningslivet än männen i samma ålder. Den typiska talespersonen i tidningarnas rapportering från lokala evenemang som marknader eller auktioner är en kvinna i 70-80-årsåldern, som länge har bott på orten och förefaller vara känd i lokalsamhället. Marknadsbesökaren på bilden nedan får illustrera denna typiska talesperson för lokala aktiviteter och evenemang.

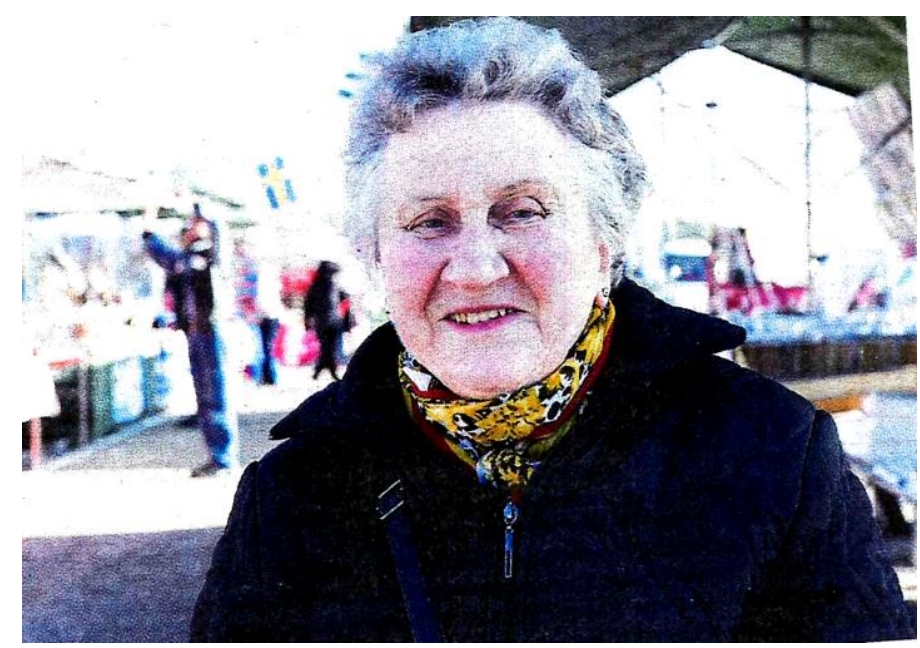

Bild 1. Margit Petersson från Vislanda på marknad. (Smp 2015-04-20)

Bild 1 sätter Margit Petersson i Vislanda i förgrunden och bakom henne i bilden ser vi marknadsstånden. Vårt material är litet, och det är inte stora skillnader i manlig och kvinnlig representation, men resultatet indikerar möjligen att kvinnor är mer vanligt förekommande i lokala och regionala mediers nyhetsrapportering än i nationell och internationell nyhetsrapportering (jfr Edström \& Jacobsson 2015:39).

Sett till fördelningen mellan äldre i olika åldersspann är fördelningen relativt jämn. I tabell 2 presenteras fördelningen av materialet. Vi har valt att dela in intervjupersonerna $\mathrm{i}$ åldersmässiga 10-årsintervall.

Tabell 2. Fördelningen mellan åldersgrupper i Smålandsposten (Smp) och Sydsvenska Dagbladet (SDS)

$\begin{array}{llll}\text { Åldersspann } & \text { Smp } & \text { SDS } & \text { Totalt } \\ 70-79 \text { år } & 5 & 10 & \begin{array}{l}15 \\ 29 \%\end{array} \\ 80-89 \text { år } & 11 & 8 & \begin{array}{l}19 \\ 37 \%\end{array} \\ & & & 17 \\ 90 \text { år och uppåt } & 7 & 10 & 33 \% \\ & & & 51 \\ \text { Totalt } & & & 100 \%\end{array}$

Som tabell 2 visar är personer i åldersgruppen 90 år och uppåt representerade i fler artiklar än personer i 70-årsåldern. Personer i åldersgrupperna 80-89 år och 90 år och uppåt kommer också till tals i flera längre nyhetsreportage i materialet. Också mycket gamla personers erfarenheter verkar alltså ses som intressant stoff för tidningarnas rapportering. I Smp förekom- 
mer exempelvis en nyhetsserie om äldres julminnen. Det är företrädesvis män och kvinnor äldre än 85 år som intervjuas i reportageserien. Ett exempel från denna serie av reportage finns under rubriken "Det blev två varv runt granen” där Asta Nilsson, 91 år, på Teleborg i Växjö berättar om sin barndoms jular:

När vi hade klätt granen och tittat på den skulle vi doppa i grytan. Det gjorde väl inte vi barn så mycket. Men mormor och morfar var med och då frågade jag varför morfar stoppade in maten $\mathrm{i}$ skägget. Det tyckte jag var konstigt. Han hade nämligen så stort skägg så att munnen inte syntes. [...] Ett starkt minne jag har var när far tog med oss in till stan för att titta på julgranen på torget. Då var det mycket snö och han spände en släde bakom hästen och lastade i oss små där. På hästen hade han hängt bjällror. (Smp 2015-12-13)

Som framgår av citatet ovan visar Asta Nilssons julminnen på kontinuitet i jultraditioner liksom att hennes julminnen tilldrar sig $\mathrm{i}$ en annan tid. I denna artikel liksom i övriga artiklar $\mathrm{i}$ samma serie är det de äldre själva som för ordet i första person. Enligt tidigare forskning framställs de riktigt gamla sällan som subjekt utan oftare som objekt i tidningarnas rapportering (se Nilsson 2008; Fealy m.fl. 2012). Så ser det alltså inte ut i vårt material, där de äldre är flest och dessutom kommer till tals i första person i reportage. Resultatet kan kanske förklaras av att en av insamlingsperioderna inföll strax före jul, då reportageserien om äldres julminnen ingick i Smp.

I båda tidningarna verkar det också finnas en tradition av att uppmärksamma lokalt kända 100-årsjubilarer genom hyllningsartiklar. I SDS förekommer exempelvis en längre artikel om två före detta elitidrottare. Artikeln skrevs i samband med att mannen fyllde 100 år, men i samma artikel uppmärksammas att hans fru snart ska fylla 103 år. Paret har varit tillsammans i 75 år. På bilden nedan syns det jubilerande paret sitta bredvid varandra i en soffa i bostaden.

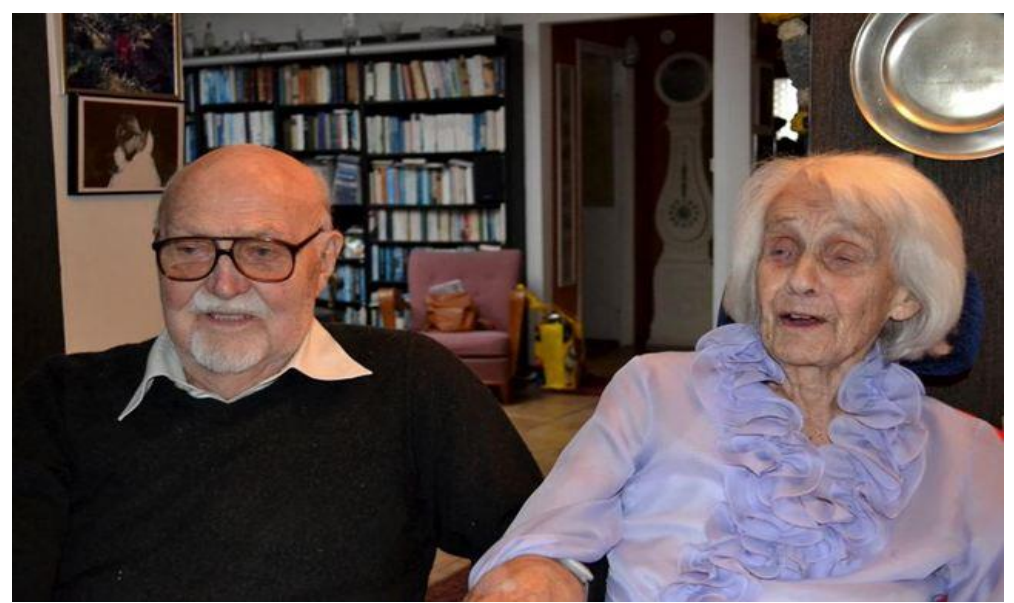

Bild 2. Lennart, 100 år, och Ingeborg Ingers, 103 år, från Rydebäck (SDS 2015-04-30)

Paret beskrivs på följande sätt i texten:

Idag, tisdag, fyller Lennart Ingers, Rydebäck, 100 år. Och på söndag blir hans hustru Ingeborg Ingers 103 år. De har varit gifta i 75 år. Snacka om rekordpar. [...] Det har handlat mycket om idrott under alla dessa år. [...] Ingeborg Ingers, eller "Kickan" Sjöqvist, som hon kallades för under sin storhetstid som idrottsstjärna, deltog i simhopp både i OS 1932 i Los Angeles och OS 1936 i Berlin. Hon kom fyra i höga hopp 1932 och nia i höga hopp 1936. Hon är världens äldsta olympier. [...] Men det många kanske inte vet är att även Lennart Ingers var en framgångsrik idrottare. Han var en duktig gymnast. (SDS 2015-04-30) 
Texten skrivs med anledning av att Lennart fyller 100 år, men artikel övergår snart till att fokusera mer på hans fru och hennes mer spektakulära idrottskarriär. När intervjun gjordes var hustrun, Ingeborg Ingers, nämligen världens äldsta olympier alla kategorier, vilket blir huvudnyheten i texten.

För representationen av svenskfödda respektive utlandsfödda äldre är det svårt att utifrån uppgifter i artiklarna dra några säkra slutsatser om hur fördelningen ser ut, i synnerhet för utlandsfödda kvinnor, som kan ha gift sig till ett svenskklingande efternamn. I Smp har alla namngivna personer svenska namn och uppges i de allra flesta fall komma från orter i Kronobergs län. Sammantaget och av de personuppgifter som förekommer i tidningens artiklar finns det ingenting som tyder på att någon av de äldre som intervjuas, omnämns eller finns på bild är utlandsfödd.

Emellertid finns i SDS-materialet uppgifter om två utlandsfödda kvinnor: den ena från Peru och den andra från Polen. Kvinnan från Peru omtalas som fru till en ensamseglare från Skanör. På bilden nedan ser vi makarna Hylén, som sitter i sin segelbåt.

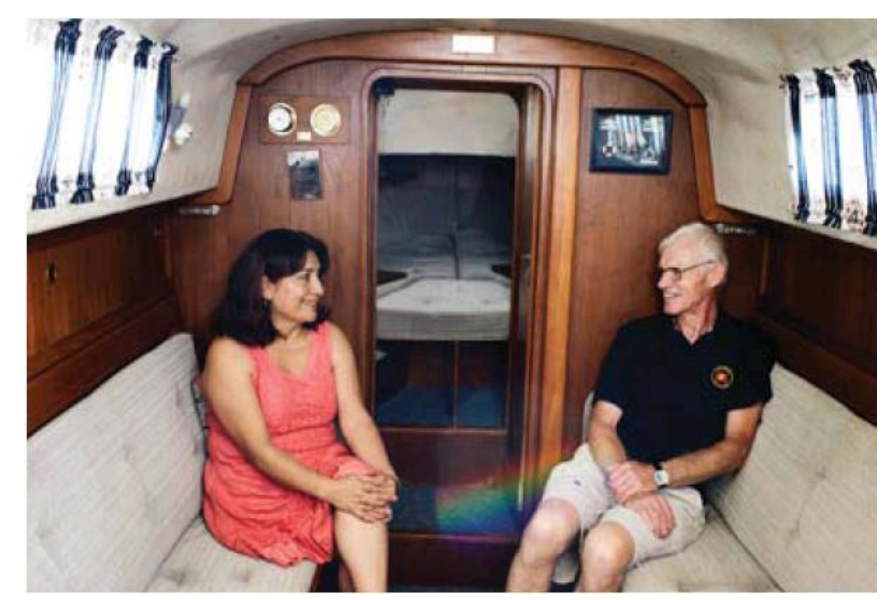

Bild 3. Nelly och Uno Hylén från Skanör (SDS 2015-04-20)

Enligt artikeln träffades paret i Peru för fyrtio år sedan, och Nelly Hylén flyttade då med sin make till Sverige för kärlekens skull. Artikeln är skriven med anledning av mannens 70-årsdag och handlar om hans intresse för långsegling. Trots detta handlar stora delar av texten om parets gemensamma liv och långa äktenskap och även om hur kvinnan har etablerat sig som lärare i spanska i Sverige:

Nelly Hylén hade lämnat allt. Hon började läsa svenska i Trelleborg. - Redan efter tre månader fick jag jobb på Gransegel i Limhamn. Jag sydde segel och var lättlärd på den tiden, säger hon. Uno Hylén fick jobb på Sjöfartsverket. [...] Segelsömnaden ledde Nelly Hylén vidare till en tjänst som grundskollärare i spanska och textilslöjd. 1984, nio år efter landstigningen i Sverige, föddes sonen Tim. Han bor i Höllviken och har nära till föräldrarna, som bor i Falsterbo. - Mitt liv har varit en öppen väg i Sverige. I skolan har jag hjälpt många barn, även trasiga barn. Och efter 40 år känner jag mig mer svensk än något annat, säger Nelly Hylén. Uno Hylén, som om några dagar fyller 70 år, har pensionerat sig och hittills skrivit runt 300 sidor på boken om sitt livs kärleksresa. Hustrun Nelly arbetar parallellt med översättning av boken till spanska. (SDS 2015-09-06) 
I citatet ovan ser vi att Uno Hyléns fru kommer till tals och bitvis framstår som textens huvudperson, och hon berättar bland annat om sitt yrkesliv i Sverige, även om artikeln företrädesvis handlar om mannen.

I en annan, längre artikel spelar en polskfödd kvinna huvudrollen. Artikeln skrevs med anledning av att det år 2015 var 60 år sedan andra världskrigets tog slut. Under rubriken "Jag har aldrig känt något hat" berättar 90-åriga Sulamit Sittsamer om sina minnen om hur det var att komma som 20-årig, judisk krigsflykting till Malmö efter att ha suttit i flera koncentrationsläger:

Minnet av ankomsten är nästan blankt. - Jag skickades till Lund. Där kantades gatorna av människor som vinkade. En del hade klättrat upp på taken. Vi kom i lumpor. Jag kände ingenting, berättar Sulamit Sittsamer, född Kurek. [...] - När jag kom till Sverige var jag mest trött. Kände ingen glädje. Men jag visste att tyskarna inte skulle komma åt oss längre. Jag har aldrig känt något hat. Är bara glad att kunna berätta om allt vi gått igenom. Men det är inte så lätt. Men jag måste orka berätta, säger Sulamit Sittsamer som har hunnit fylla 90 år. (SDS 2015-05-09)

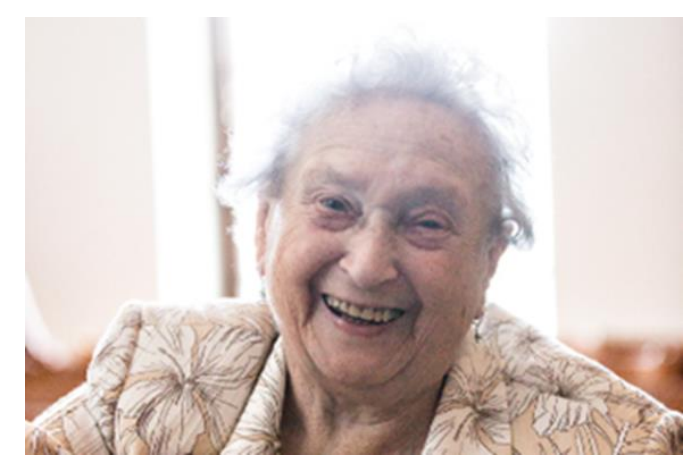

Bild 4. Sulamit Sittsamer (SDS 2015-05-10)

I artikeln berättar en överlevare från förintelsen om sitt liv, och om hur hon kände det som 20-årig när hon kom till Sverige. Artikeln om 90-åriga Sulamit Sittsamer är den enda av de 40 artiklarna där en utlandsfödd person explicit är huvudperson i texten. En gemensam nämnare för artiklarna med de utlandsfödda äldre kvinnorna är att texterna kretsar kring de utlandsföddas kamp i det gamla landet, deras resa eller flykt till Sverige, men även om att de etablerat sig väl i Sverige. Deras liv framtonar som en framgångssaga (jfr Byrman 2004).

I vårt begränsade material är det svårt att urskilja om några särskilda socioekonomiska grupper av äldre ägnas mer textutrymme än andra, baserat på exempelvis uppgifter om personers yrkestitlar eller uppgifter om personers sociala eller kulturella kapital (jfr Bourdieu 1999). Utifrån de uppgifter som finns i artiklarna tror vi oss dock kunna se en tendens till att de äldre, som framträder i längre reportage och personporträtt (jfr Siivonen 2007), är personer som tidigare i sitt liv har varit framgångsrika inom ett hantverks- eller konstnärsyrke, inom idrott, lokalpolitik eller i det lokala näringslivet. Personerna förefaller kända i det lokalsamhälle som de är en del av. "Tidigare vd", "engagerad i Rotary", "fotbollsprofill" och "styrelseledamot" är exempel på epitet som används för att markera personers sociala status. Vi illustrerar med två exempel nedan:

Fotbollsprofilen Leif lämnar snart Leifs väg 
När Leif Svahns hustru dog för några år sedan blev huset för stort. Flera av rummen har bara stått. Nya bostaden är en tvåa. Han kommer att sakna solhörnan i trädgården på Leifs väg med koltrasten sjungande i den stora granen. (SDS 2015-05-03)

Som vd med flygcertifikat tog han ibland fyrsitsigt plan till möten. Numera håller sig CarlGustaf Göthe istället på marken och trivs med att köra buss. [... ] Tidigare hade Carl-Gustaf, som nu fyller 70 år, flygcertifikat och kan i dag ångra att han släppte det. Det hände att han flög till möten i jobbet och en gång skrämde han nästan slag på en flygrädd kollega. Numera är Carl-Gustaf istället passagerare som när han och Rosita nyligen besökte Rotary-vänner i USA. Med sitt inträde i Rotary 1972 sänkte Carl-Gustaf för övrigt medelåldern betydligt. Han har också svingat en och annan golfklubba och är i dag ordförande i Glasrikets GK. (Smp 2015-0117)

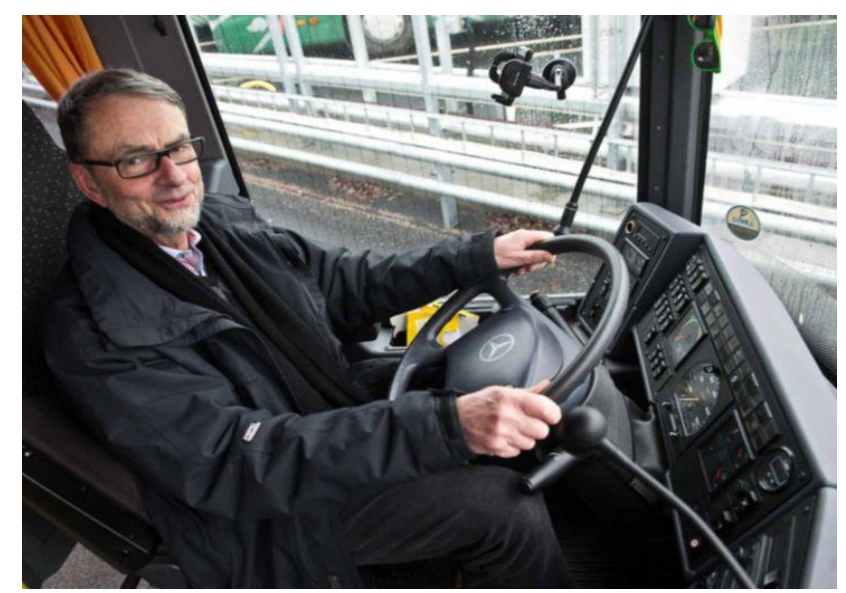

Bild 5. Carl-Gustav Göthe, en före detta vd som gärna kör buss (Smp 2015-01-17)

I exemplen är det två män som beskrivs. Den ena artikeln handlar om "fotbollsprofilen Leif", som ska byta bostad från villa till lägenhet. Den andra artikeln handlar om en tidigare vd, som nu ska fylla 70 år men som har ett aktivt liv med golfspel och busskörning. Detta illustreras genom bild 5, där Carl-Gustav sitter vid ratten i bussen som han kör. Att personerna i dessa artiklar är just en "fotbollsprofil" och "tidigare vd" förefaller vara själva orsaken till att tidningarna rapporterar om just dessa personer. Det är inget traditionellt nyhetsstoff som presenteras i artiklarna, utan nyhetsvärdet ligger enligt vår tolkning i att personerna har uppnått en viss social position i lokalsamhället eller är något av lokala kändisar.

Vi vill understryka att materialet är litet och att det inte går att dra några generella slutsatser utifrån studien, men utifrån det material vi har framträder ett entydigt mönster för hur yrkestitlar och andra epitet används kopplat till kön. Explicita, socioekonomiska markörer, som yrkestitlar och andra typer av sociala titlar, förekommer betydligt oftare i artiklar om män än i artiklar om kvinnor, vilket synliggörs i tabell 3 nedan, som presenterar epitetens fördelning mellan kvinnor och män i materialet.

Tabell 3. Förekomsten av yrkesepitet och andra socialt positionerande epitet kopplat till intervjupersonernas kön

$\begin{array}{llll} & \text { Epitet för yrken och sociala positioner } & \text { Kvinnor } & \text { Män } \\ \text { Smp } & 11 & 3 & 8 \\ \text { SDS } & 23 & 7 & 16 \\ \text { Totalt } & 34(100 \%) & 10(29,5 \%) & 24(70,5 \%)\end{array}$


Utifrån tabell 3 kan vi konstatera att yrkesepitet och andra typer av epitet för någons sociala position är vanligare i SDS-materialet och att nära två tredjedelar av epiteten i materialet totalt markerar manliga intervjupersoners sociala position.

Sammanfattningsvis visar vår kategorigenomgång att kvinnor i åldern 70 år och uppåt är fler än män, att kvinnorna också ägnas mest textutrymme sett till andelen citat och referat byggda på intervjuer med kvinnor och att kvinnorna får en hel del utrymme även i texter som företrädesvis handlar om män. Vidare framkommer det att personer i åldern 90 år eller äldre är fler i materialet än personer i 70-årsåldern. Vi har enbart identifierat två utlandsfödda personer i materialet och att dessa två publicerats i SDS. För representationen av äldre kopplat till social status verkar det företrädesvis vara äldre, som tidigare har haft en framgångsrik yrkes- eller idrottskarriär, som blir föremål för tidningarnas rapportering. Explicita epitet, som signalerar social status, är vanligare förekommande i artiklar med män som huvudpersoner.

\section{Analys av dominerande teman och äldrediskurser i tidningsartiklarna}

I det följande redovisar vi analysen och resultaten av återkommande teman som synliggjorts $\mathrm{i}$ de två dagstidningarna, och de innehållsmönster som utkristalliseras i texterna. Tabell 4 visar de studerade texternas teman i fallande frekvens.

\begin{tabular}{|c|c|c|c|}
\hline Tema & Smp & SDS & Totalt \\
\hline Arbetsliv och & 5 & 6 & 11 \\
\hline hantverkstraditioner & & & $27,5 \%$ \\
\hline $\begin{array}{l}\text { Historiska händelser och } \\
\text { lokala traditioner }\end{array}$ & 5 & 2 & $\begin{array}{l}7 \\
17,5 \%\end{array}$ \\
\hline $\begin{array}{l}\text { Sport, kultur- och före- } \\
\text { ningsliv }\end{array}$ & 3 & 3 & $\begin{array}{l}6 \\
15 \%\end{array}$ \\
\hline Boende & 1 & 3 & $\begin{array}{l}4 \\
10 \%\end{array}$ \\
\hline Hälsa och omsorg & 3 & 1 & $\begin{array}{l}4 \\
10 \%\end{array}$ \\
\hline Familj och relationer & 2 & 1 & $\begin{array}{l}3 \\
7,5 \%\end{array}$ \\
\hline Ålder & 1 & 2 & $\begin{array}{l}3 \\
7,5 \%\end{array}$ \\
\hline Resor & 0 & 2 & \\
\hline Totalt & 20 & 20 & $\begin{array}{l}100 \% \\
40\end{array}$ \\
\hline
\end{tabular}

Tabell 4 ger en översikt över teman som framträder i artiklarna; det är arbetsliv, traditioner, historiska händelser och sport som förekommer mest. Flera teman kan förekomma i en och samma artikel, men vi har valt att fokusera på vad vi har identifierat som makrotemat eller det mest dominerande temat. 
I vårt material kan vi inte se att de teman som tas upp i tabell 4 har någon tydlig koppling till män eller kvinnor utan teman är relativt jämnt fördelade. I båda tidningarna är ett framträdande tema yrkesliv och hantverkstraditioner. Personer av båda könen träder fram i längre artiklar och berättar om sitt yrkesliv och hur yrket har förändrats under åren. I artiklarna om yrkesliv och hantverkstraditioner framställs äldre genomgående som engagerade, drivande och socialt aktiva. Nedan följer några exempel:

I alla år har Margit Nordberg verkat i folkbildningens tjänst. Både för unga och äldre elever. Så har hon också blivit prisad för sina insatser. [...] Inte heller efter pensioneringen slutade Margit att undervisa, då vuxna invandrare i svenska. Efter en förfrågan från Medborgarskolan inledde Margit arbetet med Aktiva Seniorer där föreläsningar, studiebesök och resor följde. (Smp 201512-12)

I många år har Stig Ferm varit ett begrepp med sin trumpet. Och han är still going strong trots 87 år fyllda. [...] Övning har i sanning krävts när Stig inte bara skulle spela på en julotta utan ibland två. Först $\mathrm{i}$ Vederslövs kyrka klockan fem och sedan till Västra Torsås kyrka för julotta klockan sex. (Smp 2015-01-14)

Utdragen är hämtade från två artiklar ur Smålandsposten: den ena om 90-åriga, prisbelönta läraren Margit Nordberg och den andra om trumpetaren Stig Ferm, som är aktiv som musiker vid 87 års ålder. I följande utdrag får vi möta fiskaren Lars Gunnar Bergström i Skanör:

"Fiskare försöker på nytt"

I Skanörs hamn ligger de stora fritidssegelbåtarna på rad. Men längst in hamnen ligger fiskebåten Helle-Bo som påminner om hamnens forna tid som nyttohamn. Båten tillhör Lars Gunnar Bergström, en av de få kvarvarande riktiga fiskarna i hamnen. Trots att han är 72 år går han ut och vittjar näten ett par dagar i veckan.

Han berättar om år med kontroverser med konkurrenter, hamnstyrelsen och kommunen. Och förra året kom ett av de tuffaste bottennappen för hans verksamhet. Efter en anmälan från en konkurrent förbjöd Vellinge kommuns miljönämnd honom att sälja beredd fisk från hoddan. (SDS 2015-04-28)

Utdraget ovan beskriver hur den äldre fiskaren kämpar för sin existens som yrkesman mot kommunens byråkrati, trots att han passerat den gängse åldersgränsen för pensionering.

I de tre exemplen kan vi notera att journalisterna konstruerar personernas ålder som något som borde vara ett hinder för yrkesutövandet, men ett hinder som just dessa äldre har övervunnit. Uttryck som "trots att", "still going strong" och "inte heller efter pensioneringen" markerar att de äldre i artiklarna om yrkesliv och hantverk avviker från en underförstådd norm om äldre som passiva eller i varje fall inte längre yrkesaktiva. Artiklarna kan sägas vara exempel på det som Nilsson (2008) benämner en motdiskurs till mediers traditionella rapportering om äldre.

Även i artiklar på temat historiska händelser och traditioner, och i artiklar om sport, kultur och föreningsliv konstrueras både kvinnor och män som aktiva och engagerade, liksom i artiklar på temana boenden, relationer och resor. Här betonas återkommande de äldres aktivitet och förändringsbenägenhet. Äldre som bytt bostad, börjat träna på gym, rest jorden runt eller skaffat en ny partner lyfts fram i långa artiklar uppbyggda som positiva berättelser. 
I citaten nedan beskrivs långresenären Eva Jern, Gunilla Schröder-Anerud, som börjat träna på gym, och Sonja Falk och Gunnar Johansson, som blivit sambor:

"Lomma är hemmabas för orädd ensamresenär"

När Eva Jern fyllde 60 började hon resa ensam. Nu är hon 83 och har inga planer på att sluta. Under årens lopp har hon sovit under bar himmel, i tält, delat enkla rum med andra och bott $\mathrm{i}$ egen bambuhydda. (SDS 2015-09-04)

För ett par månader sedan kunde hon inte ta sig upp för en trappa. Men efter regelbunden träning klarar nu 77-åriga Gunilla Schröder-Anerud sexton trappsteg och snart räknar hon med en promenad i skogen. - Det hänger på viljan. Åldern är bara ett tal, säger hon. (SDS 2014-0115)

"Sonja och Gunnar fann kärleken på äldre dagar"

Att passera 80 behöver inte betyda att livets roliga är slut. För Sonja Falk, 85 år och Gunnar Johansson, 88 år blev det en nystart i livet och för ett år sedan flyttade de ihop. (Smp 2015-0422)

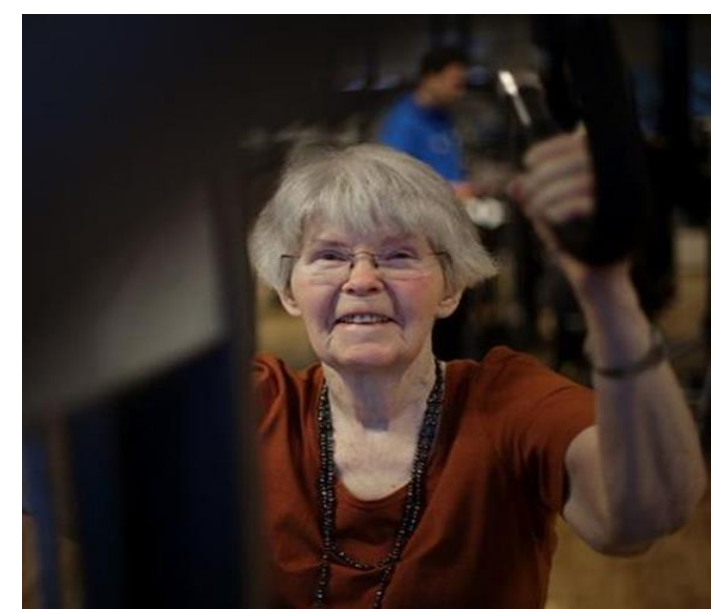

Bild 6. 77-åriga Gunilla Schröder-Anerud tränar på gym (SDS 2014-01-15)

Exemplen skildrar personer som har åstadkommit en positiv förändring i sitt liv. Vi kan alltså konstatera att den dominerande diskursen om äldre i vårt material är en som inte låter åldern bli ett hinder för aktivitet och engagemang. Det är en övervägande positiv och hoppfull framställning av äldre och åldrande som dominerar. Men genom dessa skildringar framträder också en outtalad norm om att pensionärer idag förväntas se aktivitet och förändring som något eftersträvansvärt; åldrandet verkar underförstått ses som en process som bör fördröjas eller bekämpas genom aktivitet (jfr Nilsson 2008:192).

En annan bild av äldre framträder dock i ett par artiklar om äldrevård och äldreboenden. Där framställs äldre antingen som offer för bristande omsorg eller som tacksamma brukare av kommunens äldreomsorg. Nedan följer två exempel; det första handlar om en kvinna vars trygghetslarm slutade att fungera. Det andra handlar om en man som flyttat in i ett nybyggt äldreboende:

När 90-åriga Anna-Lisa Tobiazon behövde akut hjälp tryckte hon på sitt trygghetslarm. Men eftersom att Wexnet hade ett avbrott nådde larmet in fram till hemtjänsten. Inte förrän hon gick in till grannarna som hade en mobiltelefon kunde hon larma efter ambulans. (Smp 2015-04-25) 
Igår kunde Kenneth Fransson äntligen flytta in i sin lägenhet på Solsidan i Alvesta. Solsidan ligger i anslutning till äldreboendet Högåsen och har tolv lägenheter för särskilt boende. - Jag tror det här kommer att bli bra, säger Kenneth Fransson. (Smp 2015-01-16)

Det första exemplet belyser bristen i vården. Det är kvinnans son som är hennes talesperson, och kvinnan får ingen egen röst i artikeln. Det andra exemplet ingår i en artikel om ett nytt äldreboende i Alvesta, där Kenneth Fransson är den första hyresgästen som flyttar in. I de här artiklarna är det inte äldre som färgstarka individer som står i fokus, utan snarare lyfts enskilda äldre fram som exempel på äldre i behov av vård och omsorg (jfr Fealy m.fl. 2012: 91). Diskursen kan uppfattas som objektifierande, även om mannen som flyttat in på det nya boendet kommer till tals i första person; texterna förefaller primärt att handla om kommunal äldreomsorg, hur den inte fungerar respektive fungerar.

En tredje konstruktion av äldre framträder i artiklar om hantverkstraditioner, historiska händelser och jultraditioner. I artiklar med dessa teman framstår de äldre som kulturbärare, som värnar om att hålla äldre hantverkstraditioner och bygdens minnen vid liv. Vi illustrerar med två exempel; det första handlar om Birgitta Blixt och hennes arbete med folkdräkter, och det andra om hur en grupp pensionärer arbetar med bokbinderi:

"Birgitta har ett genuint intresse för folkdräkter"

Dräkthistoria. Intresset för textil började redan under barndomen. Genom folkdansen kom intresset för dräkthistoria. Det har blivit en bok och nu är Birgitta Blixt även aktuell som klädansvarig i en kommande amatörteater. (Smp 2015-01-12)

"Flit och kärlek ger längre bokliv"

I omkring tjugo år har ett gäng bokbinderifrälsta pensionärer regelbundet samlats på Bäckagårdens äldreboende i Skanör. Erik Hjelmquist har varit med från början. Kärleken till litteratur - särskilt sådan som berör Stockholm och dess lokalhistoria - är en stark drivkraft. Jag har mellan 1700 och 2000 böcker hemma. Gränsen för att få kalla samlingen för bibliotek lär gå vid tusen, säger han. (SDS 2014-01-14)

Att konstruera äldre som kulturbärare, som håller äldre hantverkstraditioner levande, känns igen från tidigare forskning om hur äldre brukar representeras i medier (jfr Nilsson 2008:92). I denna traditionsdiskurs kan de äldre ses som tillbakablickande och nostalgiska. Men vi vill betona att den dominerande framställningen av äldre i vårt material framställer äldre som framåtblickande och delaktiga i alla möjliga olika typer av sociala aktiviteter och sammanhang.

\section{Skillnader i framställningen av kvinnor och män}

I det studerade materialet finns inga märkbara skillnader om vilka teman kvinnor respektive män kopplas till. Däremot har vi uppmärksammat några generella skillnader i hur äldre kvinnor och män beskrivs. Vi har noterat att äldre kvinnors klädsel och utseende ibland blir föremål för journalisternas beskrivningar, medan inga motsvarande beskrivningar om manliga intervjupersoners utseende förekommer. Nedan följer två exempel; det första är från en intervju med 100-åriga Sonja Sernhed i Åseda. Hon beskrivs på följande sätt: 
I en av sina röda fåtöljer tar hon emot. Hon har klätt sig fin i knytblus och plisserad blå kjol och satt på sig pärlhalsband. [...] Hon har nagellack redan nu, men vill bli lite extra fin till födelsedagen. (Smp 2015-01-14)

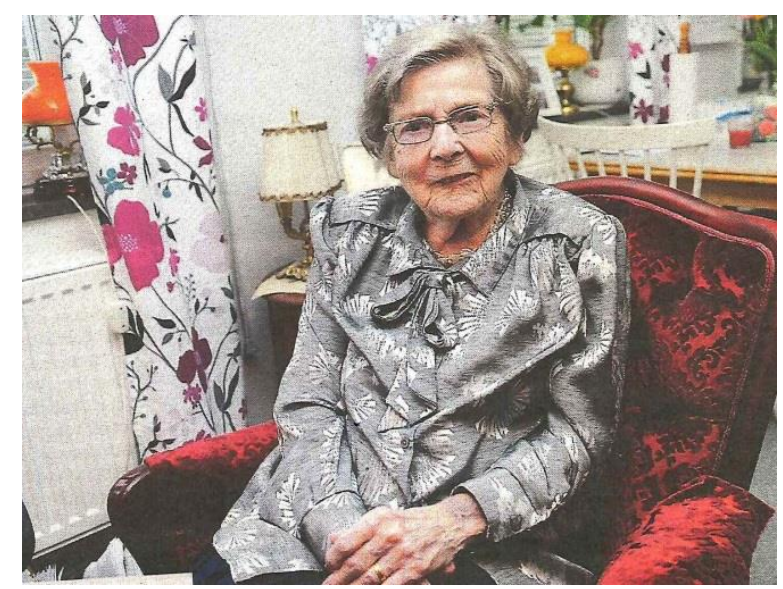

Bild 7. Sonja Sernhed, 100 år (Smp 15-01-14)

Artikeln ovan publicerades med anledning av att huvudpersonen fyllt 100 år, och Sonja Sernhed berättar bland annat om sitt tidigare engagemang i pingstförsamlingen. Förutom att kvinnan intervjuas om sitt liv och föreningsengagemang får vi i utdraget ovan en beskrivning av hennes utseende. Utseendebeskrivningen har inte någon koppling till innehållet i intervjun. Texten beskriver även hur fint den 100-åriga kvinnan har det i sitt rum på seniorboendet.

Ett annat exempel är hämtat från en artikel om en egenföretagare och hårfrisörska, Ingegärd Parstam, som i 50 år har drivit en välbesökt salong i Malmö:

Hon har själv hängt med i trenderna. När hon nyöppnade salongen på Sofielund passade hon på att klä upp sig ordentligt med krulligt rött hår, leopardkjol och höga stövlar. Tur att rösten är sig lik, kommenterade en kund, annars hade han inte känt igen henne. (SDS 2015-05-02)

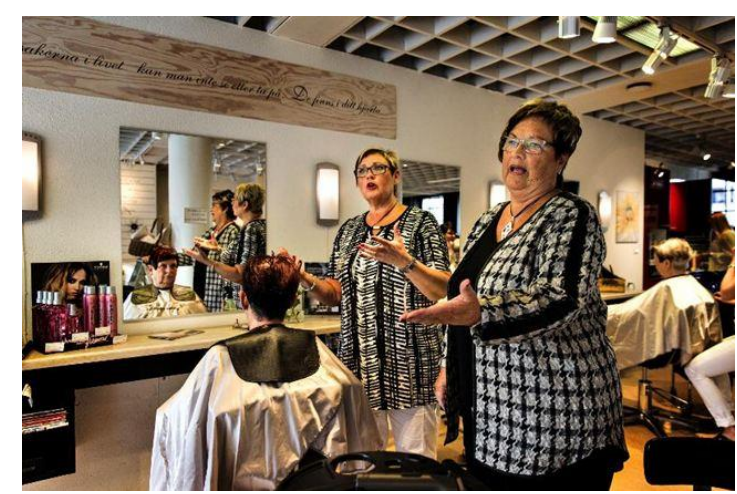

Bild 8. Ingegärd Parstam i sin salong i Malmö (SDS 2015-04-30)

I denna artikel berättar företagaren själv om hur det har varit att driva salongen, men i utdraget ovan beskrivs den kvinnliga företagaren ur ett utifrånperspektiv och med fokus på hennes utseende snarare än på hennes yrkesprofession, som är makrotemat för texten. Företagaren uttalar sig i texten om hårmodet förr och nu, vilket möjligen kan ses som en förklaring till varför journalisten ser det som relevant att kommentera att intervjupersonen "själv hängt med i trenderna" och att hon hade "krulligt rött hår" när hon nyöppnade salongen. Utseendebeskrivningen "i leopardkjol och höga stövlar" faller dock utanför ämnet hårmode. 
När äldre män beskrivs i texter som berör deras yrkesliv, är det framför allt männens plikttrogenhet och höga arbetsmoral som accentueras. I SDS förekommer exempelvis en artikel om en 84-årig bokhandlare, som ska pensionera sig efter att bokhandeln gått i konkurs:

"Hamrelius i konkurs efter krisig julhandel"

Han är 84 år och har arbetat sexdagarsvecka, utan ordentlig semester de senaste tolv åren. Som 21-åring, för 63 år sedan, började Hamrelius på Hedengrens bokhandel vid Stureplan i Stockholm. [...] 2004 flyttade Hamrelius bokhandel till en ny stor butikslokal på Södergatan. På Södergatan hade vi tusen kvadrat. Det var för häftigt, säger Gudmund Hamrelius. [...] - Jag är ledsen för branschen om den fysiska bokhandeln inte överlever. Den fysiska bokhandeln är ett viktigt showroom för branschen. (SDS 2014-01-15)

Genom exemplet ovan får vi inblick i bokhandlaren Gudmund Hamrelius arbetsliv. Beskrivningen framtonar som en meritförteckning (jfr Byrman 2004, Siivonen 2007). Det nämns bland annat att bokhandlaren har arbetat sexdagarsvecka och inte tagit semester under de senaste 12 åren. I materialet finns också andra artiklar om män, som betonar just deras plikttrogenhet i arbetet, alternativt hur viktigt deras arbete har varit för lokalsamhället. Se exempelvis följande utdrag ur en artikel om en 89-årig man, som tidigare arbetat som linjemontör i Älmhult:

89-årige Stig Hansson arbetade i 40 år med att ge Älmhultsborna el. Arbetet var tungt, livsfarligt och på helt andra villkor än i dag. (Smp 2015-01-16)

Utifrån de exempel vi här har presenterat kan vi konstatera att det finns genusstereotypa konstruktioner av kvinnor och män i några av artiklarna, men i materialet som helhet vill vi framhålla att dessa inslag är få. Den dominerande diskursen om aktiva och engagerade äldre företräds av såväl kvinnor som män. Detta kan ses som ett utslag av att de äldre blivit en stor och aktiv grupp i hela samhället.

\section{Slutsatser och diskussion om studiens kategorier och teman}

Journalister har genom sin nyhetsvärdering makt att avgöra vilka personer som tillåts ta plats och komma till tals i tidningarna (jfr Lundström 2004:25-26). Mediernas nyhetsrapportering kan antas nå ut till och ha potential att påverka läsarnas bild av i vilka samhällssammanhang äldre personer deltar och vilka dessa äldre kvinnor och män är - deras sociala status och etnicitet. Därför bör mediernas äldrekonstruktioner kritiskt granskas och diskuteras. I denna genuskritiska och komparativa studie har vi utifrån ett diskursanalytiskt och intersektionellt perspektiv (jfr Nordenstam 2003, Fairclough 2010; de los Reyes \& Mulinari 2005) undersökt hur personer i åldern 70 år och uppåt framställs i två dagstidningars lokala eller regionala rapportering. Med ett intersektionellt perspektiv på tidningarnas äldrekonstruktioner har vi försökt synliggöra hur representationen av äldre ser ut inte bara kopplat till genus, utan också till de äldres etniska och sociala bakgrund.

Mot bakgrund av tidigare forskning överraskar några av studiens resultat. Ett är att kvinnor och personer över 80 år är överrepresenterade i materialet, vilket förklaras av att båda tidningarna verkar ha en tradition av att uppmärksamma hundraåringar som i någon mån är lokalt kända. Den äldrediskurs som dominerar i materialet representerar äldre personer som 
framåtblickande och aktiva i sammanhang som tidigare inte har förknippats med personer i hög ålder. Återkommande är berättelser om äldre som gjort en omstart sent i livet, exempelvis genom att börja träna på gym eller genom att inleda en ny kärleksrelation. En annan trend är att i artiklar som skrivs om män som är i en relation eller gifta övergår texten också till att handla om männens partner. Således kan vi konstatera att kvinnor inte är underrepresenterade i detta material på det sätt som rapporterats från andra studier (jfr Edström \& Jacobsson 2015).

Enligt Nilsson (2008) har det under senare år börjat växa fram en motdiskurs om aktiva äldre, som en reaktion mot mediernas tidigare mer negativa rapportering om äldre som antingen tillbakablickande eller som offer för olika vårdskandaler. Denna motdiskurs om aktiva äldre är dominerande i vårt material. Detta kan i och för sig ha att göra med våra urvalskriterier; vi har valt ut just artiklar som har enskilda äldre som huvudpersoner, snarare än äldre som grupp.

Andra slutsatser som vi drar är att personer som tidigare i livet har haft en hög social status i den lokala miljön, och förefaller vara kändisar i densamma, dominerar i den lokala nyhetsrapporteringen om enskilda äldre. Vidare kan vi konstatera att utlandsfödda äldre är underrepresenterade i materialet. När utlandsfödda äldre intervjuas handlar texterna nästa uteslutande om personens flytt eller flykt till Sverige.

Många olika teman framträder i artiklar med äldre som förebilder i skrift och bild; till de dominerande temana hör yrkesliv och hantverkstraditioner, historiska händelser och jultraditioner och sport samt kultur- och föreningsliv. I dessa teman berörs både kvinnor och män, men kvinnor är överrepresenterade som talespersoner för lokala evenemang som till exempel marknader och föreningsträffar.

Vi ser dock en tendens till stereotypa genuskonstruktioner genom att mäns sociala status oftare än kvinnors markeras explicit genom yrkesepitet och andra socialt positionerande epitet, som till exempel "vd" och "ordförande". I materialet förekommer också beskrivningar av äldre kvinnors utseende och klädsel, medan inga motsvarande beskrivningar förekommer i texterna om äldre män. I representationen av äldre män betonas i stället männens plikttrogenhet och arbetsamhet. På så sätt uppvisar studien likheter med tidigare forskning om hur kvinnor och män framställs i medierna (jfr Jarlbro 2006; Byrman 2004 och 2015, Siivonen 2007). Oberoende av ålder förefaller kön vara avgörande för hur journalister väljer att karakterisera den intervjuade. Det görs fortfarande i häpnadsväckande traditionella genuskategorier.

Sammantaget visar studien att genom tillägg av ett intersektionellt perspektiv erhålls en mer nyanserad bild av äldre kvinnor och män, där kvinnorna får mer spaltutrymme än mannen, även om ett traditionellt synsätt på män och kvinnor framträder i de studerade dagstidningarna.

\section{Referenser}

Bailey, Terri Ann. 2010. Ageism and Media Discourse: Newspaper Framing of Middle Age. I: Florida Communication Journal, 38 (1). S. 43-56.

Bourdieu, Pierre. 1999. Praktiskt förnuft: bidrag till en handlingsteori. Göteborg: Daidalos. Byrman, Gunilla. 1998. Tidningsnotisen i förändring: 1746-1997. Lund: Institutionen för nordiska språk, Lunds universitet. 
Byrman, Gunilla. 2004. Manligt och kvinnligt på familjesidan. I: Humanetten, nr 15. [Hämtad 2016-03-09: https://open.lnu.se/index.php/hn/article/view/206].

Byrman, Gunilla. 2015. Familjenyheter i svenskt medielandskap. En jämförelse av text och genus över tid. I: Jenny Magnusson, Karin Milles \& Zoe Nikolaidou (red.). Könskonstruktioner och språkförändringar: Rapport från den åttonde konferensen om språk och kön. Huddinge: Södertörns högskola. S. 47-69.

Crenshaw, Kimberle. 2008. The curious resurrection of first wave feminism in the U.S. elections: An intersectional critique of the rhetoric of solidarity and betrayal. I: GEXcel work in progress report. Vol. 3, Proceedings from GEXcel theme 1: Gender, sexuality and global change spring 2008. S. 27-38.

De los Reyes, Paula \& Mulinari, Diana. 2005. Intersektionalitet: kritiska reflektioner över (o)jämlikhetens landskap. Malmö: Liber.

Edström, Maria \& Jacobsson, Josefine. 2015. Räkna med kvinnor: Global Media Monitoring Project 2015. Nationell rapport Sverige. [Allt är möjligt]. [Hämtat 2017-01-04: http://cdn.agilitycms.com/who-makes-the-news/Imported/reports_2015/national /Sweden.pdf].

Fairclough, Norman. 2010. Critical discourse analysis: the critical study of language. Harlow: Longman.

Fealy, Gerard, McNamara, Martin, Pearl Treacy, Margret \& Lyons, Imogen. 2012. Constructing ageing and age identities: a case study of newspaper discourses. I: Ageing and Society, nr 1/2012. S. 85-102.

Findahl, Olle. 2015. Pensionärerna och internet 2014 [Elektronisk resurs]. Stockholm:.SE [Hämtad 2017-01-04: https://www.iis.se/docs/Pensionarerna_och_internet_2014.pdf].

Gill, Rosalind. 2007. Gender and the media. Cambridge: Polity.

GMMP 2016. [Hämtat 2017-01-02 http://whomakesthenews.org/about-us/media---gendermonitor].

Gustavsson, Cecilia. u.å. Min generation, kap. 1. Publicerad på Aftonbladets webbplats. [Hämtad 2017-01-05 http://mingeneration.story.aftonbladet.se/].

Jarlbro, Gunilla. 2006. Medier, genus och makt. Lund: Studentlitteratur.

Lundström, Gunilla. 2004. När tidningarna blev moderna: om svensk journalistik 18981969. Göteborg: Nordiskt informationscenter för medie- och kommunikationsforskning (NORDICOM-Sverige).

Nilsson, Magnus. 2008. Våra äldre: om konstruktioner av äldre i offentligheten. Linköping: Institutionen för samhälls- och välfärdsstudier, Linköpings universitet.

Nilsson, Magnus \& Jönsson, Håkan. 2009. Äldre i massmedierna: osynliga eller förknippade med problem. I: Åldrande, åldersordning, ålderism. S. 96-104.

Nordenstam, Kerstin. 2003. Genusperspektiv på språk [Elektronisk resurs]. Stockholm: Högskoleverket i samarbete med Nationella sekretariatet för genusforskning. [Hämtad 2017-01-03].

Nygren, Klara (red.) 2012. Konstruktiv normkritik: en rapport om normkritik $i$ Europeiska socialfondens projekt. 1. uppl. Stockholm: Arbetsmiljöforum i Sverige/Tema Likabehandling.

Ross, Karen (red.) 2012. The handbook of gender, sex, and media [Elektronisk resurs]. Malden: Wiley-Blackwell.

Siivonen, Jonita. 2007. Personporträttet som tidningsgenre: en närläsningsstudie med fokus på innehållsliga teman, berättarkonventioner och kön. Doktorsavhandling i kommunikationslära. Helsingfors: Svenska social- och kommunalhögskolan vid Helsingfors universitet. 